\title{
A polystyrene mouse cage
}

\section{A. JONES From the Medical Research Council Industrial Injuries and Burns Research Unit, Birmingham Accident Hospital}

Current experimental work in the healing of surface wounds of mice required that these animals should be kept in isolation, under close observation, and free from infection. Cages were required which would occupy a minimum of bench space and be readily cleaned, disinfected and stored.

The cages were constructed from polystyrene food containers, size 4 in. $\times 4$ in. $\times 3$ in. (obtainable from A. R. Horwell Ltd. of London). Air holes were made in the lids by drilling about 50 holes $1 / 8$ in. in diameter; if larger holes were used the mice were able to gnaw at the periphery of the holes, enlarge them and escape. A hole, $5 / 8$ in. diameter, was made in one corner of the lid to accommodate the water bottle, and was fitted with $\frac{1}{2}$ in. brass eyelets as used by sail makers (Fig. 1).

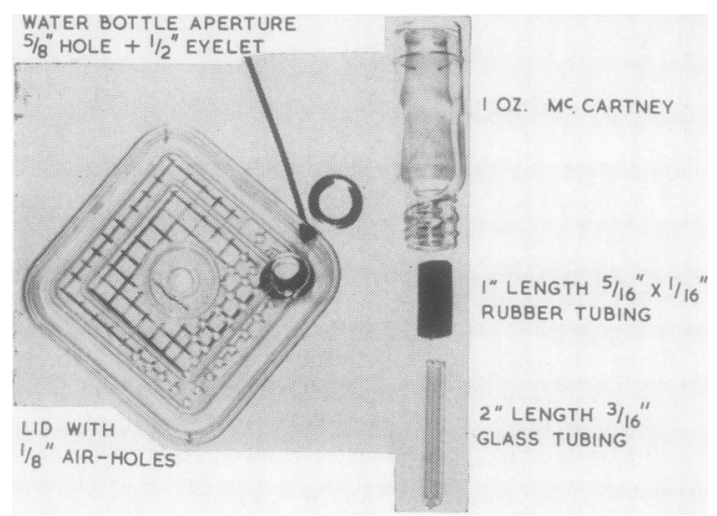

FIG. 1

McCartney bottles were used for the water supply. The mouthpiece was constructed from a 2 in. length of $5 / 8$ in. outside diameter glass tubing, one end being constricted to about $3 / 32$ in. by heating in a Bunsen flame. Rubber tubing 1 in. in length, which fitted tightly over the glass tube, was pushed over the other end of the mouthpiece to make a firm fit both in the neck of the bottle and the brass eyelet at the corner of the cage.

In use, the lids of the cages were held in place with broad elastic bands (Fig. 2). As risks of infection had to be minimized, sawdust, which had heen previously autoclaved at $15 \mathrm{lb}$. for 15 minutes, was used. The cages after use were cleaned in warm running water and disinfected by immersion for five minutes in $0.5 \%$ aqueous chlor-

Received for publication 24 October 1963.

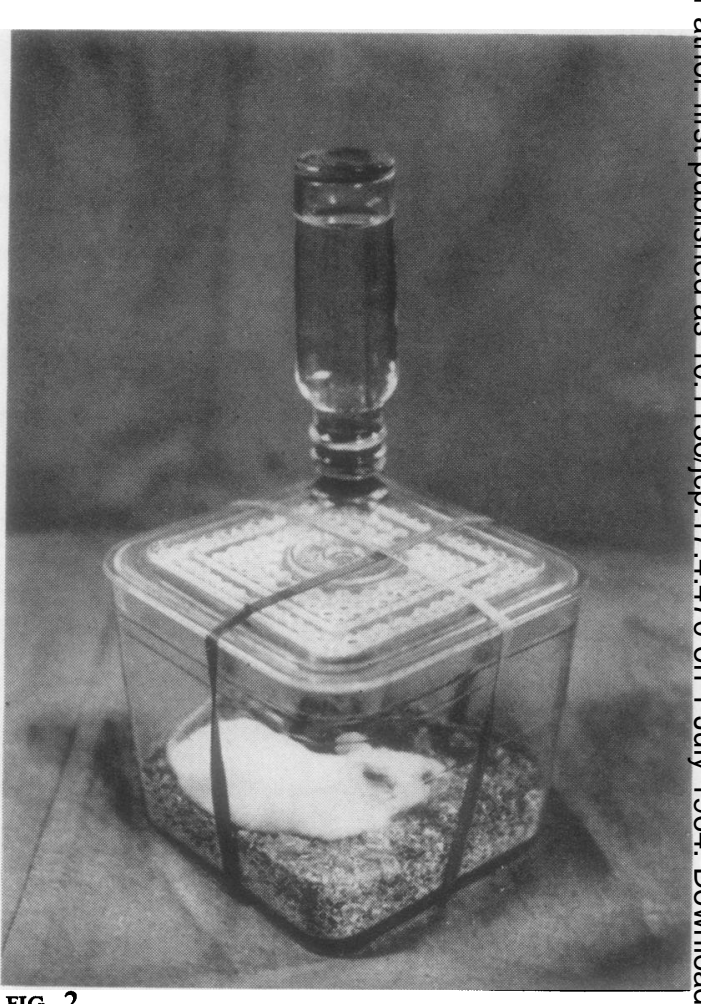

hexidine diacetate. Excess moisture was removed and drying completed in a glassware drying cabinet at $50^{\circ} \mathrm{CO}$ Higher temperatures caused the polystyrene to warp.

The advantages of these cages are that they are ligh? allow easy handling and cleaning, take up little space. while in use or being stored, and all parts are inter changeable. It was also found that intravenous taff injections were simplified by holding the tail through the eyelet hole, the mouse remaining in the cage. The floo area is $10.6 \mathrm{sq}$. in., which approximates to the $11.0 \mathrm{sq}$. in? recommended in the Universities Federation for Anima Welfare Handbook (1957).

During a series of experiments with 50 mice over period of six months, involving the changing and cleaning of these cages well over 1,000 times, no infection witr. pathogenic bacteria was observed.

Thanks are due to Dr. R. J. Jones and Dr. J. C. Lawrenc? for suggestions and encouragements.

\section{REFERENCES}

Universities Federation for Animal Welfare (1957). Handbook of the Care and Management of Laboratory Animals, edited by A. N. Worden and W. Lane-Petter, 2nd ed., p. 245. UFAW London. 